\title{
BRINGING THE QUESTION OF CHINESE IPR ENFORCEMENT TO THE WTO UNDER TRIPS: AN EFFECTIVE STRATEGY OR A MEANINGLESS AND OVERUSED TACTIC BY THE U.S.?
}

\author{
Jung Yun (Jennifer) Yang*
}

\section{INTRODUCTION}

China has had a long history of high levels of piracy and counterfeiting. Leaders of China's Food and Drug Administration have confessed that their pharmaceutical market is immersed in fake and deadly drugs. ${ }^{1}$ In addition, DVD's and VCD's ${ }^{2}$ containing pirated versions of Chinese and foreign films or television series are easily found in China's major cities. ${ }^{3}$ Since China is the world's fastest growing economy and the contributor of the largest trade deficit to the United States (U.S.) (U.S. \$268 billion in 2008), ${ }^{4}$ it is no surprise that the issue of Intellectual Property Right (IPR) counterfeiting and piracy are of national interest to the U.S..

For years the U.S. has voiced its complaints about piracy and counterfeiting activities in China, and the United States Trade Representative (USTR) has had China on its Priority Watch List for allegedly not providing an adequate level of IPRs protection or enforcement. ${ }^{5}$ Unable to resolve U.S. concerns, the U.S. initiated a WTO dispute against China in April of 2007 - DS362: China Measures Affecting the Protection and Enforcement of Intellectual Property Rights. ${ }^{6}$ Specifically,

\footnotetext{
*Jung Yun (Jennifer) Yang is currently a third-year law student at University of Pittsburgh School of Law. She is expected to earn her Juris Doctor in May, 2010.

**Special thanks to Professor Janewa Osei-Tutu, Visiting Professor of Law at University of Pittsburgh School of Law (2009-2010), for her thoughtful comments and input as I developed this paper.

${ }^{1}$ David Barboza, A Chinese Reformer Betrays His Cause, and Pays, N.Y. Times, July 13, 2007, at A1, available at http://www.nytimes.com/2007/07/13/business/worldbusiness/13corrupt.html.

${ }^{2}$ Video $\mathrm{CD}$, abbreviated as VCD, is a standard digital format for storing video on a Compact Disc. Wikipedia, Video CD, http://en.wikipedia.org/wiki/Video_CD.

${ }^{3}$ See Rogier Creemers, The Effects of WTO Case DS362 on Audiovisual Media Piracy in China, Eur. InTELL. Prop. REV. (forthcoming 2009) (manuscript at 1), available at $\mathrm{http}: / / \mathrm{ssrn} . \mathrm{com} / \mathrm{abstract}=1434914$.

${ }^{4}$ U.S. Census Bureau, Foreign Trade Statistics, Trades in Goods (Imports, Exports and Trade Balance) with China, http://www.census.gov/foreign-trade/balance/c5700.html.

${ }^{5}$ See Office of the U.S. Trade Rep., 2005 Special 301 Report 1 (Apr. 29, 2005); Office of the U.S. Trade Rep., 2006 Special 301 Report 1 (Apr. 28, 2006); Office of the U.S. Trade Rep., 2007 Special 301 Report 2 (Apr. 30, 2007); Office of the U.S. Trade Rep., 2008 Special 301 Report 19 (Apr. 30, 2008).

${ }^{6}$ See generally Panel Report, China-Measures Affecting the Protection and Enforcement of Intellectual Property Rights, WT/DS362/R (Jan. 26, 2009), available at http://www.wto.org/english/tratop_e/dispu_e/362r_e.pdf [hereinafter Panel Report].
} 
the U.S. charged China with violating its obligations under the Trade Related Aspects of International Property Rights (TRIPS) ${ }^{7}$ Agreement. The U.S. brought three claims concerning copyright, customs, and criminal law. ${ }^{8}$

In January of 2009, the WTO panel found a number of shortcomings in the protection of IPRs in China that were incompatible with TRIPS obligations. ${ }^{9}$ According to the WTO panel, it is a violation of TRIPS for China to refuse copyright protection of works that do not meet China's legal standards. ${ }^{10}$ Additionally, simply removing an infringing trademark as the only precondition for the sale at public auction of counterfeit goods seized by Chinese customs authorities was found impermissible. ${ }^{11}$ The panel, however, found insufficient evidence to conclude that China's threshold for prosecution in its criminal law was a violation of TRIPS. ${ }^{12}$ Both parties accepted the panel's findings, and China negotiated with the U.S. to implement the recommendations by March of $2010 .^{13}$

The outcome of this WTO case is relevant for various reasons. Despite what the USTR regarded as a favorable ruling for the U.S., ${ }^{14}$ this panel decision did not translate into substantive improvements in intellectual property (IP) protection and enforcement in China. The outcome of this WTO case revealed limitations of the WTO forum in implementing IPR enforcement obligations under TRIPS against China in matters related to copyright piracy and trademark counterfeits. Furthermore, the case reaffirms the view that pressuring China to make certain legislative changes in order for the

\footnotetext{
${ }^{7}$ Agreement on Trade-Related Aspects of Intellectual Property Rights, Apr. 15, 1994, Marrakesh Agreement Establishing the World Trade Organization, Annex 1C, 1869 U.N.T.S. 299, 33 I.L.M. 1197 (1994) [hereinafter TRIPS Agreement].

${ }^{8}$ See generally Panel Report, supra note 6.

${ }^{9} \mathrm{Id}$.

${ }^{10} \mathrm{Id}$.

${ }^{11} \mathrm{Id}$.

${ }^{12} \mathrm{Id}$.

${ }^{13}$ Communication from China and the United States, China-Measures Affecting the Protection and Enforcement of Intellectual Property Rights - Communication from China and the United States Concerning Article 21.3(b) of the DSU, WT/DS362/13 (Mar. 7, 2009).

${ }^{14}$ Press Release, USTR, United States Wins WTO Case over Deficiencies in China's Intellectual Property Laws (Jan. 26, 2009), http://www.ustr.gov/about-us/press-office/press-releases/2009/january/united-states-wins-wto-dispute-overdeficiencies-c.
} 
country to comply with internationally mandated obligations, such as TRIPS, may not be the U.S.'s best approach to fighting counterfeiting and piracy. Therefore, this article seeks to propose a better alternative: China should be allowed time to develop into a country which is better equipped to enforce IPRs and fully comply with its TRIPS obligations.

\section{ENFORCEMENT OF THE TRIPS AGREEMENT}

\section{A. THE TRIPS AGREEMENT}

In most countries, copyright piracy and trademark counterfeiting are considered crimes. ${ }^{15}$ There are differences, however, in the ways that countries enforce their IPR laws.

The TRIPS Agreement was negotiated as part of the Uruguay Round of Multilateral Trade Negotiations in $1986,{ }^{16}$ and after seven years of highly contentious negotiations, the agreement was signed in 1994 and came into force on January $1,1995 .{ }^{17}$ As a result of the emergence of TRIPS, the main forum for rulemaking shifted from the World Intellectual Property Organization (WIPO), a specialized United Nations agency dedicated to promoting the protection of IP around the world, ${ }^{18}$ "to the newly created [WTO], and [the agreement] transform[ed] the substantive rules" of previous international IP standards. ${ }^{19}$

The TRIPS Agreement represented the "furthest reach of multilateral harmonization [and] [integration] efforts," and from the perspective of developed countries, the substantive terms of the TRIPS Agreement were desirable and more protective than existing international IP accords. ${ }^{20}$ While it adopted many provisions of previous multilateral treaties administered under WIPO, such as

\footnotetext{
${ }^{15}$ Martin K. Dimitrov, Piracy and the State 1 (2009).

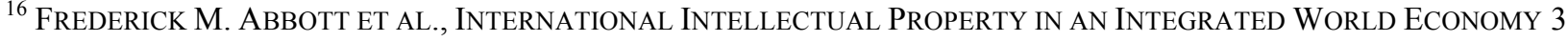
(2007). 
the Paris Convention for the Protection of Industrial Property ${ }^{21}$ and Berne Convention for the Protection of Literary and Artistic Works, ${ }^{22}$ the TRIPS Agreement provided more stringent "minimum standards" or minimum levels of IPR protection. ${ }^{23}$

One very important innovation of the TRIPS Agreement was the availability of enforcement measures of IPR, ${ }^{24}$ which were absent in the Paris Convention and the Berne Convention. The TRIPS Agreement requires members to establish effective yet "fair and equitable" procedures for the enforcement of IPRs, including providing remedies to prevent further infringement. ${ }^{25}$ Members are $^{25}$ obligated to provide IPR holders with access to civil judicial procedures to enforce their rights, ${ }^{26}$ and parties are given the opportunity to present evidence. ${ }^{27}$ In addition, damages and injunctions are available. ${ }^{28}$ Judges are given the authority to order the destruction of infringing goods. ${ }^{29}$ Members must provide procedures under which IPR holders provide notice to customs authorities of suspected shipments of infringing goods, and to establish procedures for the suspension of entry into commerce. ${ }^{30}$ Members are also required to make available criminal procedures and penalties for willful trademark infringement and copyright piracy on a commercial scale. ${ }^{31}$ The TRIPS Agreement entered a new international legal ground when it imposed obligations on WTO members to adequately and effectively enforce IPRs.

\footnotetext{
${ }^{21}$ Paris Convention for the Protection of Industrial Property, as last revisited at the Stockholm Revision Conference, July 14, 1967, 21 U.S.T. 1583, 828 U.N.T.S. 305 (concluded in 1883) [hereinafter Paris Convention].

${ }^{22}$ Berne Convention for the Protection of Literary and Artistic Works, adopted Sept. 9, 1886, S. Treaty Doc. No. 99-27, 1161 U.N.T.S. 3 [hereinafter Berne Convention].

${ }^{23}$ TRIPS Agreement, supra note 7, art. 1.3.

${ }^{24}$ Id. Part III.

${ }^{25} I d$. art. 41.

${ }^{26} I d$. art. 42.

${ }^{27} I d$. arts. $42-43$.

${ }^{28} I d$. arts. $44-45$.

${ }^{29} I d$. art. 46.

${ }^{30} \mathrm{Id}$. art 51 .

${ }^{31} I d$. art. 61.
} 


\section{B. ENFORCEMENT OF TRIPS BY THE WTO: DISPUTE SETTLEMENT PROCESS}

With the emergence of the TRIPS Agreement within the WTO framework, a new centralized procedure for resolving IP-related disputes was introduced: the Understanding on Rules and Procedures Governing the Settlement of Disputes (DSU). ${ }^{32}$ Article 64.1 of TRIPS grants members access to the WTO dispute settlement mechanism for disputes arising under TRIPS. ${ }^{33}$ The DSU lays out a structured procedure for dispute resolution arising under the WTO. The WTO contains a single unified body that administers all disputes, the Dispute Settlement Body (DSB). ${ }^{34}$ Panels of governmental and nongovernmental individuals who objectively assess the facts of each case and apply the necessary rules to make recommendations or rulings assist the DSB. ${ }^{35}$ Furthermore, the DSU allows parties to appeal a panel's decision to the Appellate Body, a permanent entity consisting of seven judges. ${ }^{36}$ The DSU automatically adopts the report of the panel and Appellate Body, ${ }^{37}$ unless there is a unanimous objection within a reasonable timeframe. ${ }^{38}$

The DSB will request that the offending member remedy the inconsistency if a panel or the Appellate Body rules that a particular measure is inconsistent with a member's treaty obligations. ${ }^{39}$ If the losing party fails to implement the recommendations and the rulings within a reasonable time, the DSU allows for compensation and the suspension of concessions or treaty obligations as remedial measures. ${ }^{40}$

\footnotetext{
${ }^{32}$ Understanding on Rules and Procedures Governing the Settlement of Disputes, Marakesh Agreement Establishing the World Trade Organization, Annex 2, Legal Instruments - Results of the Uruguay Round, 33 I.L.M. 112, 1226 (1994) [hereinafter DSU].

${ }^{33}$ TRIPS Agreement, supra note 7, art. 64.1.

${ }^{34} \mathrm{DSU}$, supra note 32 , art. 2.

${ }^{35}$ World Trade Organization, Annex 2: Understanding on Rules and Procedures Governing the Settlement of Disputes, 358, 360, http://www.wto.org/english/docs_e/legal_e/28-dsu.pdf (last visited Dec. 1, 2009).

${ }^{36}$ DSU, supra note 32, art. 17.

${ }^{37}$ See Glen T. Schleyer, Power to the People: Allowing Private Parties to Raise Claims Before the WTO Dispute Resolution System, 65 FORDHAM L. REV. 2275, 2286 (1997).

${ }^{38}$ DSU, supra note 32, arts. 16.4, 17.14.

${ }^{39}$ Yang Guohua, Bryan Mercurio \& Li YongJie, WTO Dispute Settlement Understanding: A Detailed INTERPRETATION 223 (2005).

${ }^{40}$ World Trade Organization, supra note 35 , at 368.
} 
Despite previously having had membership in WTO's predecessor, the General Agreement of Tariffs and Trade (GATT) in 1948, it took approximately fifteen years of exhaustive negotiations for China to formally attain membership to the WTO in $2001 .^{41}$ Threatened by the country's size and economic growth rate, China had to make heavy concessions to make its WTO accession desirable to the European Community (EC) and the U.S. ${ }^{42}$ Among many of the commitments made conditional to its WTO entry, China promised to implement the TRIPS Agreement in full, including the enforcement provisions, from the date of accession. ${ }^{43}$

For China, WTO membership means more than obtaining economic leverage. ${ }^{44}$ According to scholar Dr. Jing Gu, "China is concerned with its identity in the international community, as its political and even military and security interests are affected by progress in the domain of international trade. ${ }^{45}$ In other words, China's purpose for attaining WTO membership was "to better protect its interests, [to] actively to involve itself in the development of the rules of multilateral trade regime, including through [WTO] DSU mechanism, and to build up its international image. ${ }^{, 46}$

\section{WTO DS362: U.S. V. CHINA}

\section{A. FIRST CLAIM: COPYRIGHT LAW}

The U.S.'s first claim addressed China's denial of copyright protection and enforcement to works that are not in accordance with China's censorship regulations. According to the U.S., Article

\footnotetext{
${ }^{41}$ Press Release, WTO Successfully Concludes Negotiations on China's Entry, WTO (Sept. 17, 2001), available at http://www.wto.org/english/news_e/pres01_e/pr243_e.htm; see also World Trade Organization, Accession of the People's Republic of China, Nov. 23, 2001, available at http://docsonline.wto.org/imrd/directdoc.asp?DDFDocuments/t/WT/L/432.doc.

${ }^{42}$ See generally World Trade Organization, Report of the Working Party on the Accession of China, Nov. 10, 2001, available at http://www.wto.org/english/thewto_e/acc_e/protocols_acc_membership_e.htm (follow "Report of the Working Party" hyperlink) (outlining the special terms in which China negotiated with other members of the WTO to attain membership).

${ }^{43}$ Press Release, supra note 41.

${ }^{44}$ Jing Gu, China and the WTO, InST. OF DEv. STUDIES, UK, at 1, http://www.die-gdi.de/CMSHomepage/openwebcms3.nsf/(ynDK_FileContainerByKey)/ADMR-7BBFVT/\$FILE/JingGu China and the WTO.pdf?Open.

${ }^{45} \overline{I d}$.

${ }^{46} I d$. at 3 .
} 
4 of China's Copyright Law did not provide the protection to all works that was required under Article 9.1 of TRIPS because the law denied copyright protection to works that had been banned for publication, distribution or both under Chinese law. ${ }^{47}$ Furthermore, since the enforcement provisions under China's Copyright Law were unavailable with respect to works denied copyright under Article 4 of that law, this was arguably inconsistent with the enforcement requirement under Article 41.1 of the TRIPS Agreement. ${ }^{48}$

China counter-argued that Art. 4(1) of its Copyright Law merely provides that a work that fails content review is not protected by its Copyright Law, but this did not deny the copyright protection required under TRIPS. ${ }^{49}$ Responding to the U.S. claim concerning Article 41 of TRIPS, China contended that the publication prohibition measures constituted effective actions as demanded by TRIPS. ${ }^{50}$ It also argued that its copyright enforcement procedures were available for right holders of any work to go to court and seek remedies. ${ }^{51}$

The panel found that a category of works denied protection under Article 4(1) of the Copyright Law was inconsistent with Article 5(1) of the Berne Convention, as incorporated by Article 9.1 of the TRIPS Agreement. The relevant portion of Article 4(1) at issue is as follows: "[w] Law." According to the panel, Article 4 (1) on its face was inconsistent with Article 5(1) of Berne, thereby violating China's obligation under TRIPS.

Article 9.1 of the TRIPS Agreement provides as follows:

Members shall comply with Articles 1 through 21 of the Berne Convention (1971) and the Appendix thereto.

\footnotetext{
${ }^{47}$ Panel Report, supra note 6, para. 3.1.

${ }^{48}$ Id. para. 7.161 .

${ }^{49}$ Id. para. 7.162 .

${ }^{50}$ Id. para. 7.164 .

${ }^{51} I d$.

${ }^{52}$ Copyright Law (promulgated by the Standing Comm. 7th Nat'1 People's Cong., Sept. 7, 1990, effective Jun. 1, 1991, revisited Oct. 27, 2001), art. 4(1), translated in CHINA.ORG.CN China (last visited Dec. 1, 2009) (P.R.C.) [hereinafter Copyright Law (P.R.C.)].
} 
Article 5(1) of Berne created the national treatment obligation, ${ }^{53}$ where there are "the rights which their respective laws do now or may hereafter grant to their nationals." there are also "the rights specially granted by [the Berne Convention]." 55 Although "the rights specially granted"" are not defined, the panel held that it "refer[red] to rights that authors shall enjoy in respect of works."

The panel explained that the "works" denied protection under Article 4(1) of Chinese Copyright Law applied to some, if not all, categories of works that should be protected under Article 5 of Berne Convention, ${ }^{57}$ including the works that had failed content review and the deleted portions of works edited to pass content review which were not afforded protection under Article 4(1) of China's law. ${ }^{58}$ Although Article 17 of the Berne Convention gives governments certain rights to control the exploitation of works, ${ }^{59}$ the panel elaborated that copyright protection of private rights ${ }^{60}$ was clearly distinguishable from government censorship addressing public interest; ${ }^{61}$ therefore, there was no reason to assume that the right to censorship would entirely eliminate copyright protections to private copyright owners against third parties from exploiting prohibited works under Article 5(1) of Berne. ${ }^{62}$

As to Article 41.1 of TRIPS, the panel reviewed Chapter V of China's Copyright Law, entitled "Legal Liabilities and Enforcement Measures."63 Under Chapter V, "Article 46 provide[d] for civil liability for [eleven] types of acts of infringement," and "Article 47 provide[d] for civil and

\footnotetext{
${ }^{53}$ Panel Report, supra note 6, para. 7.106.

${ }^{54}$ Berne Convention, supra note 22, art. 5(1).

${ }^{55} \mathrm{Id}$.

${ }^{56}$ Panel Report, supra note 6, para. 7.107.

${ }^{57}$ Id. para. 7.115 .

${ }^{58}$ Id. para. 7.103.

${ }^{59}$ Berne Convention, supra note 22, art. 17.

${ }^{60} \mathrm{See}$ fourth recital of the preamble to the TRIPS Agreement.

${ }^{61}$ Panel Report, supra note 6, para. 7.135.

${ }^{62}$ Id. para. 7.139.

${ }^{63}$ Id. para. 7.166.
} 
administrative liability and investigation of criminal liability for eight specific types of action.",64 Enforcement procedures under the Copyright Law included "orders to cease infringement, to pay compensation for damages and to confiscate the products of infringement, and provisional measures to order discontinuation of the infringement and to preserve property." ${ }^{, 65}$

The panel held that since a right holder of a work denied copyright protection under Article $4(1)$ of the Copyright Law was denied rights of private copyright enforcement, ${ }^{66}$ China's law was inconsistent with TRIPS Article 41.1, which requires enforcement procedures against "any act of infringement of intellectual property rights covered by [the TRIPS Agreement]."67

\section{B. SECOND CLAIM: CUSTOMS MEASURES}

In its second claim, the U.S. contended that China's Customs Law was inconsistent with Articles 46 and 59 of the TRIPS Agreement ${ }^{68}$ because the law created a scheme giving Chinese customs authorities the option of disposing IP-infringing goods seized at the border instead of destroying the goods, thereby encouraging the infringing goods to enter the channels of commerce. ${ }^{69}$

China responded that in reading Article 59 of TRIPS in conjunction with Article 1.1 of TRIPS, its customs officers possessed flexibility and had wide discretion to determine whether its obligation under Article 59 was met. ${ }^{70}$

The Customs IPR Regulations and relevant Implementation Measures and Public Notices set out that confiscated goods shall be handled in the following order:

1. donating the goods to public welfare bodies or assigning the goods to the IP rights holder with compensation;

2. auctioning the goods after completely eradicating the infringing features and packaging of the goods; and

3. destroying the goods if the infringing features cannot be eradicated. ${ }^{71}$

\footnotetext{
${ }^{64} I d$.

${ }^{65} I d$. para. 7.167.

${ }^{66}$ Copyright Law art. 4(1) (P.R.C.).

${ }^{67}$ Panel Report, supra note 6, para. 7.175; TRIPS Agreement, supra note 7, art. 41.1.

${ }^{68}$ Panel Report, supra note 6, para. 7.197.

${ }^{69} \mathrm{Id}$.

${ }^{70}$ Id. para. 7.198 .
} 
Article 59 of TRIPS in relevant part provides as follows:

[C]ompetent authorities shall have the authority to order the destruction or disposal of infringing goods in accordance with the principles set out in Article $46 \ldots$. .

Article 46 of TRIPS provides as follows:

In order to create an effective deterrent to infringement, the judicial authorities shall have the authority to order that goods that they have found to be infringing be, without compensation of any sort, disposed of outside the channels of commerce in such a manner as to avoid any harm caused to the right holder, or, unless this would be contrary to existing constitutional requirements, destroyed. . . In regard to counterfeit trademark goods, the simple removal of the trademark unlawfully affixed shall not be sufficient, other than in exceptional cases, to permit release of the goods into the channels of commerce. ${ }^{72}$

The panel found that Article 59 of TRIPS only obliged competent authorities to have the authority to make certain orders - "“destruction or disposal.",73 The panel said that remedies ordered "'in such a manner as to avoid any harm caused to the right holders'" found in Article 46 of TRIPS was only applicable when the infringing products were disposed outside the channels of commerce. ${ }^{74}$ According to the panel, if goods were sold for charitable distribution, "the goods were not in fact disposed of outside the channels of commerce but into the channels of commerce."75 Furthermore, "[i]f social welfare bodies charitably distributed goods donated to them by [c]ustoms [authorities] but the goods later find their way back into the channels of commerce, this does not alter the fact that the goods were disposed outside the channels of commerce, in the ordinary sense of 'disposal.", 76

\footnotetext{
${ }^{71}$ See Regulations on Customs Protection of Intellectual Property Rights (promulgated by the State Council of the People's Republic of China, Dec. 2, 2003, effective Mar. 1, 2004), art. 27, translated in CHINA CUSTOMS (last visited Dec. 1, 2009) (P.R.C.).

${ }^{72}$ TRIPS Agreement, supra note 7, art. 46.

${ }^{73}$ Panel Report, supra note 6, para. 7.249.

${ }^{74}$ Id. para. 7.244.

${ }^{75}$ Id. para. 7.279.

${ }^{76}$ Id.
} 
Since the disposal of infringing goods outside the channels of commerce was an alternative to destruction of the goods, ${ }^{77}$ "any inherent risk of harm due simply to the fact that the goods had not been completely destroyed [was] insufficient to disqualify a disposal method, as it would nullify the choice between disposal and destruction."78 The panel also found no evidence that customs authorities would donate defective or dangerous goods to charity since Chinese law required the confiscated goods to be used for social public welfare and could not be used to the detriment of public interest. ${ }^{79}$ In situations where goods were donated to organizations like the American Red Cross, the recipients would not likely be misled to the origin of the goods, nor would it lead to damaging or harming a right holder's reputation. ${ }^{80}$ Therefore, the panel concluded that the U.S. failed to demonstrate that Customs lacked authority to donate goods to social welfare bodies in such a manner as to avoid any harm to the right holder caused by lower quality goods. ${ }^{81}$ The panel also upheld the use of sales and auctions as legitimate disposal options. ${ }^{82}$

However, in situations where counterfeit trademark goods were being released into the channels of commence, TRIPS required more than the simple removal of the trademark, except in exceptional cases. ${ }^{83}$ In this regard, according to the panel, China's customs measures violated Article 46 of TRIPS, which stated that "the simple removal of the trademark unlawfully affixed [was] sufficient to permit release of the goods into the channels of commerce," allowing release of goods into the channels of commerce "in more than just 'exceptional cases.",

\footnotetext{
${ }^{77}$ Id. para. 7.282

${ }^{78} \mathrm{Id}$.

${ }^{79} I d$. para. 7.291-7.293.

${ }^{80}$ Id. para. 7.297.

${ }^{81} \mathrm{Id}$.

${ }^{82}$ Id. paras. 7.325-7.353.

${ }^{83}$ TRIPS Agreement, supra note 7, art. 46.

${ }^{84}$ Panel Report, supra note 6, paras. 7.393-7.394.
} 


\section{THIRD CLAIM: CRIMINAL THRESHOLDS}

The last claim brought by the U.S. concerned China's high thresholds for criminal procedures and penalties. The U.S. alleged that the high thresholds violated Article 61 of the TRIPS Agreement because they allowed Chinese infringers to structure their commercial operations to ensure that they operated below the relevant threshold evading any criminal liabilities. ${ }^{85}$ By implementing these high thresholds, the U.S. contended that China violated Article 41 of TRIPS, which obligates member countries to provide means for enforcement resulting in effective action. ${ }^{86}$

China's main argument was that it employed reasonable and appropriate criminal thresholds for counterfeiting and piracy purposes in compliance with Article 41 and 61 of the TRIPS Agreement. ${ }^{87}$ China employed a narrower and more common usage understanding of "“"commercial scale"” under Article 61 of TRIPS to mean "a significant magnitude of infringement activity." China relied on Articles $1.1^{89}$ and $41.5^{90}$ of TRIPS ${ }^{91}$ to define the standards of Article 61 of TRIPS, explaining that it retained considerable discretion with respect to law enforcement.

The panel concluded that some acts of copyright infringement might possibly fall below all thresholds, thereby not being enforced by criminal proceedings, but that this did not necessarily mean that it was a violation of Article 61 of TRIPS. ${ }^{92}$

\footnotetext{
${ }^{85}$ First Written Submission of the United States, China - Measures Affecting the Protection and Enforcement of Intellectual Property Rights, p. 2, WT/DS362 (Jan. 30, 2008), available at http://www.iftaonline.org/Uploads/Issues/58.pdf [hereinafter First Submission].

${ }^{86}$ Panel Report, supra note 6, para. 7.676; see also TRIPS Agreement, supra note 7, art. 41 ("Members shall ensure that enforcement procedures ... are available under their law so as to permit effective action against any act of infringement of [IPR]s ....").

${ }^{87}$ Panel Report, supra note 6, para. 7.425.

${ }^{88} I d$. para. 7.481.

${ }^{89}$ TRIPS Agreement, supra note 7, art. 1.1 ("Members shall be free to determine the appropriate method of implementing the provisions of this Agreement within their own legal system and practice.").

${ }^{90} I d$. art. 41.5 ("does not create any obligation to put in place a judicial system for the enforcement of [IPRs] distinct from that for the enforcement of law in general, nor does it affect the capacity of Members to enforce their law in general.").

${ }_{91}$ Panel Report, supra note 6, para. 7.481.

${ }^{92} I d$. para. 7.669.
} 
Under Article 61 of the TRIPS Agreement, members are required to "provide for criminal procedures and penalties ... at least in cases of wilful trademark counterfeiting or copyright piracy on a commercial scale."93 According to the panel, "counterfeiting or piracy 'on a commercial scale' refers to counterfeiting or piracy carried on at the magnitude or extent of typical or usual commercial activity with respect to a given product in a given market." ${ }^{94}$ According to this definition, "counterfeiting or piracy of a particular product [would] depend on the magnitude or extent that is typical or usual with respect to such a product in such a market" in China. ${ }^{95}$

The panel reviewed the measures and concluded that "on their face, they did not exclude certain commercial activity from criminal procedures and penalties." 96 For example, “[c]ertain thresholds [were] set in monetary terms, ranging from $¥ 20,000$ profit to $¥ 50,000$ turnover or sales,, 97 but this did not indicate what this amount represented as compared to a relevant commercial benchmark in China. ${ }^{98}$ Another threshold was set in the amount of copies, but this again did not relate to any relevant market benchmark in China either, according to the panel. ${ }^{99}$ The panel especially criticized the U.S.'s evidence, including articles ${ }^{100}$ and press articles about the Chinese market, ${ }^{101}$ as being insufficient and uncorroborated to demonstrate a level that constituted a commercial scale for any product in China. ${ }^{102}$ According to the panel, the U.S. did not satisfy its burden of proof. ${ }^{103}$

\footnotetext{
93 TRIPS Agreement, supra note 7, art. 61.

${ }^{94}$ Panel Report, supra note 6, para. 7.577.

${ }^{95}$ Id.

${ }^{96}$ Id. para. 7.609.

${ }^{97}$ Id. para. 7.610; see also Criminal Law (promulgated the revised ed. by the Standing Comm. 5th Nat'1 People's Cong., Mar. 14, 1997, effective Oct. 1, 1997), arts. 214, 215, 217, 218, translated in ASIAN LII (last visited Dec. 1, 2009) (P.R.C.).

${ }_{98}$ Panel Report, supra note 6, para. 7.610.

${ }^{99}$ Id.

${ }^{100} I d$. para. 7.616 .

${ }^{101}$ Id. para. 7.627.

${ }^{102}$ Id. paras. 7.617, 7.628.

${ }^{103} I d$. para. 7.681. Furthermore, the panel did not rule on the claim under Article 41.1 of TRIPS, exercising its judicial economy. Id. para. 7.682 .
} 


\section{IMPLICATIONS OF THE U.S.-CHINA WTO IP CASE}

Although it appears that the U.S. has prevailed in the majority of its claims, the victory seems to be rather meaningless for the U.S in terms of actual curtailing of the piracy and counterfeiting levels in China. After tracking the development of IPRs in China and analyzing the repeated attempts by the U.S. government to enforce IP laws there, it can be strongly suggested that even had the WTO panel ruled in favor of the U.S., finding that China had violated its obligations under TRIPS on all three claims, this ruling would have had minimal impact on China actually satisfying the U.S.'s notion of adequate IPR protection and TRIPS compliance. Minimal amendment of Chinese laws, in reality, will not fight against counterfeiting and piracy.

\section{A. IMMEDIATE EFFECTS}

At this juncture, China does not have to change its criminal prosecution thresholds for IP violations under TRIPS. From the U.S. perspective, China will continue to lack enforcement on its criminal side by maintaining "safe harbor" provisions, which will allow criminals to commit the IP infringement below the specified threshold without the fear of legal prosecution. ${ }^{104}$

The bigger problem, however, seems to be that despite the panel's rulings that found China's copyright protection and its customs disposal system of counterfeited goods to be in violation of its obligations under TRIPS, ${ }^{105}$ implementing the recommendations of the panel in order for China to comply with TRIPS will not be burdensome on China. Implementing the recommendations will involve amending and changing laws and regulations on their face, rather than China having to change its application or enforcement of existing laws. Winning a favorable WTO ruling in this DS362 dispute, however, will most likely not result in the desired effect of dropping piracy and

\footnotetext{
${ }^{104}$ Office of the U.S. Trade Rep., 2006 Report to Congress on China's WTO Compliance 74 (2006), available at http://ustraderep.gov/assets/Document_Library/Reports_Publications/2006/asset_upload_file688_10223.pdf.

${ }^{105}$ See generally Panel Report, supra note 6.
} 
counterfeiting rates. The problem at issue does not seem to arise from China's reluctance to amend and enact domestic laws, giving higher IPRs, but rather from China's failure to enforce such laws.

In the past, China has significantly changed its written IP laws to comply with the WTO obligations under TRIPS. The strengthening of its IP laws, however, does not correlate to effective IP protection. For example, Articles 9 through 13 of TRIPS cover copyrights. ${ }^{106}$ Artistic rights, including literary works, music, and visual arts, require copyright protection. ${ }^{107}$ Today, China's copyright law ${ }^{108}$ meets many of the TRIPS obligations. It protects works created by Chinese citizens, while international treaties or bilateral agreements protect works created by foreign citizens. ${ }^{109}$ The law includes remedies such as (1) injunctions, ${ }^{110}$ (2) confiscation of infringing goods as well as the materials used to create them, and (3) criminal liabilities, ${ }^{111}$ as required by TRIPS. ${ }^{112}$ Compared to China's prior copyright law, the current version aligns with its obligation under TRIPS. Yet although China has copyright laws which attempt to comply with TRIPS, there is still rampant pirating activity reported. "Available statistics on copyright piracy indicate that 88 percent of business software (e.g., Microsoft Office) in use in China in 2005 was pirated, leading to losses in the U.S. of $\$ 1.3$ billion from unrealized sales". ${ }^{113}$ Overall, losses from all types of copyright piracy in China that same year amounted to $\$ 2.4$ billion. ${ }^{114}$

Similarly, considering China's weak enforcement apparatus, China's compliance with the panel's recommendations, to provide copyright protection to prohibited works and comply with a different disposal method by March of 2010, will likely bring limited legislative impact and not

\footnotetext{
106 TRIPS Agreement, supra note 7, arts. 9-13.

107 See Deli Yang, InTellectual Property And Doing Business in China 92 (Pervez N. Ghauri ed., 2003).

${ }^{108}$ Copyright Law (P.R.C.).

${ }^{109} I d$. art. 2.

${ }^{110} I d$. art. 49 ,

${ }^{111}$ Id. art. 47.

${ }^{112}$ See TRIPS Agreement, supra note 7, art. 44 (injunctions); art. 45 (damages); art. 46 (other remedies); art. 61 (criminal procedures).

113 DimitROV, supra note 15 , at 16.

${ }^{114}$ International Intellectual Property Alliance, IIPA 2004-2005 Estimated Trade Losses Due to Copyright Privacy, February 13, 2006, http://www.iipa.com/pdf/2006SPEC301LOSS.pdf.pdf (number is in U.S. dollars).
} 
assist in protecting copyright holders. Even if the U.S. had hypothetically won its criminal threshold claim, compliance with TRIPS, under this WTO DS362 dispute, would have merely required China to legislatively lower its threshold for triggering criminal penalties for IP infringement. There would have been no assurance that China would adequately enforce such amended legislation.

\section{B. U.S. REACTION TO CHINA'S IP ENFORCEMENT}

The author's contention that bringing China to the WTO forum to resolve counterfeiting and piracy under TRIPS will have no immediate and desirable effect is further strengthened if one analyzes the historical steps that the U.S. employed against China. History teaches the U.S. that imposing economic sanctions or imposing threatened power will not effectively deter counterfeiting and piracy activities.

For many years China had not developed any notion of IPRs. It was not until the twentieth century, as foreign business and investment in China increased substantially, that IP piracy posed a serious problem. ${ }^{115}$ To retain proper IPR protections, the U.S. first used its military and economic prowess to provoke China into signing a commercial treaty in 1903. This treaty granted IPRs protection to Americans in return for IPRs protection for the Chinese. ${ }^{116}$ Even after signing this treaty, China took years to introduce substantive IP laws: a copyright law in 1910, a patent law in 1912, and a trademark law in $1923 .^{117}$ The preambles to these laws, however, offered foreigners very little IP protection.

\footnotetext{
${ }^{115}$ William P. Alford, To Steal a Book is an Elegant OfFense: Intellectual Property LaW in Chinese Civilization 34 (1995).

${ }^{116}$ See Treaty for Extension of the Commercial Relations Between [China and the United States], reprinted in Treaties and Agreements with the Concerning China 1894-1919, No. 1903/5 (J.V.A. MacMurray ed., 1921). This treaty represented "one of the first efforts by the United States anywhere to use its strength bilaterally to bring about greater intellectual property protection." Id. See also William P. Alford, Making the World Safe for What? Intellectual Property Rights, Human Rights and Foreign Economic Policy in the Post-European Cold War World, 29 N.Y.U.J. INT'L L. \& POL. 135, 138 (1997).

${ }^{117}$ ALFORD, supra note 115 , at 37, 41-42.
} 
"After the fall of the Qing dynasty, ${ }^{118}$ China experienced 'decades of wars,' famines, and revolutions ... [IPRs] did not return until the Chinese Communist Party reopened the country to the international community in the late 1970s." ${ }^{119}$ Unlike the previous ruler, "Deng Xiaoping saw economic wealth as the foundation of China's power and realized that China could not modernize in isolation without the benefits of foreign science, technology, capital, and management skills." ${ }^{120}$ As such, China began pushing for restoration of diplomatic and commercial ties with the U.S. and other developed countries, eventually becoming a member of the WIPO. ${ }^{121}$ Eventually, China advanced with promulgating a new trademark law in $1982^{122}$ and a patent statute in $1984 .{ }^{123}$ It also joined the Paris Convention in $1985 .{ }^{124}$ Despite China's efforts, these new laws as well as bilateral and multilateral agreements gave very limited protection to authors and inventors. China, at that time, "remained very reluctant to introduce private property rights, as [it] [was] concerned about the conflict [IPRs] would create within the socialist economic system."125 "Thus, instead of creating new rights to protect individual authorship and inventions, the new [IP] statutes were ... primarily to rehabilitate authors ... and inventors by enhancing their position through legal recognition while promoting 'socialist legality with Chinese characteristics", ${ }^{126}$

In the late 1980s and early 1990s, "the U.S. government repeatedly threatened China with a series of economic sanctions, trade wars, non-renewal of Most-Favored Nation [] status, and

\footnotetext{
${ }^{118}$ Qing Dynasty was the "last ruling dynasty of China, ruling from 1644 to 1912 . . . It was preceded by the Ming Dynasty and followed by the Republic of China". Wikipedia, Qing Dynasty, http://en.wikipedia.org/wiki/Qing_Dynasty.

${ }^{119}$ Peter K. Yu, The Sweet and Sour Story of Chinese Intellectual Property Rights, in Technology, Progress and Prosperity: A History of Intellectual Property and Development 3 (Graham Dutfield \& Uma Suthersanen eds., Palgrave Macmillan, forthcoming 2010) (citing Peter FenG, InTEllectual Property LAW In ChinA 3 (1997)).

${ }^{120} \mathrm{Id}$. at 3-4.

121 Member since June 1980. World Intellectual Property Organization, China (CN), http://www.wipo.int/aboutip/en/ipworldwide/pdf/cn.pdf.

${ }^{122}$ Trademark Law (promulgated by Standing Comm. 5th Nat'1 People's Cong., Aug. 23, 1982, effective Mar. 1, 1983), translated in Judicial PROTECTION OF IPR IN CHINA (last visited Dec. 1, 2009) (P.R.C.).

${ }^{123}$ Patent Law (promulgated by Standing Comm. 6th Nat'1 People's Cong., Mar. 12, 1984, effective Apr. 1, 1984), translated in JUDICIAL PROTECTION OF IPR In CHINA (last visited Dec. 1, 2009) (P.R.C.).

${ }^{124}$ World Intellectual Property Organization, Paris Notification No. 114, Accession by the People's Republic of China (Dec. 19, 1984), http://www.wipo.int/treaties/en/html.jsp?file=/redocs/notdocs/en/paris/treaty_paris_114.html.

${ }^{125} \mathrm{Yu}$, supra note 119, at 4.

${ }^{126} I d$.
} 
opposition to [China's] entry into the [WTO]." ${ }^{\text {2127 }}$ Because of these threats, China was repeatedly coerced into signing bilateral agreements that intended to show China's commitment to IP protection with the U.S., These agreements included the Memorandum of Understanding on the Protection of Intellectual Property Rights in 1992, ${ }^{128}$ the Agreement Regarding Intellectual Property Rights in $1995,{ }^{129}$ and a similar agreement in $1996 .{ }^{130}$ Nevertheless, piracy and counterfeiting remained widespread in China. The rampant piracy in China led to a loss of approximately $\$ 2$ billion of revenues annually for the U.S. in the late 1980s and early 1990s. ${ }^{131}$ "According to one industry estimate, $99 \%$ of all computer software in China was pirated in the late 1990s."132

The USTR has continuously put China under its Priority Watch List and threatened unilateral actions against China for its inadequate IP protection. ${ }^{133}$ Under Section 182 of the Trade Act of 1974 and the Special 301 Provisions of the Uruguay Round Agreements Act of 1994, the "USTR must identify countries that deny adequate or effective protection for IPRs or deny fair and equitable market access for persons that rely on [IP] protection." ${ }^{\text {134 }}$ If the problem continues to remain after a six to nine month consultation, the U.S. has an option to withdraw trade benefits or impose sanctions. $^{135}$

After reviewing the previous efforts by the U.S. to secure stronger IPR protection and enforcement from China, it seems clear that threatening China with economic sanctions or other

\footnotetext{
${ }^{127}$ Peter K.Yu, From Pirates to Partners: Protection Intellectual Property in China in the Twenty-First Century, 50 AM. U. L. REV. 131, 133, 140-51 (2000) (describing the U.S.' use of section 301 sanctions and various trade treaties to induce China to protection IPR).

${ }_{128}$ Memorandum of Understanding on the Protection of Intellectual Property, U.S.-P.R.C., Jan. 17, 1992,34 I.L.M. 676.

129 Agreement Regarding Intellectual Property Rights, P.R.C.-U.S., Feb. 26, 1995, 34 I.L.M. 881.

130 Implementation of the 1995 Intellectual Property Rights Agreement-1996, June 17, 1996, P.R.C.-U.S., available at http://tcc.export.gov/Trade_Agreements/All_Trade_Agreements/exp_005361.asp (last visited Nov. 14, 2009).

131 Yu, supra note 119 , at 6; see also Seith Faison, China Turns Blind Eye to

Pirated Discs, N.Y. TIMES, Mar. 28, 1998, at D1, available

at http:/www.nytimes.com/1998/03/28/business/international-business-china-turns-blind-eye-to-pirated-disks.html.

${ }^{132} \mathrm{Yu}$, supra note 119 , at 6 .

${ }^{133}$ See Office of the U.S. Trade Rep. Annex 1: Statutory Background on Special 301(last visited Nov. 20, 2009), http://www.ustr.gov/sites/default/files/Annex\%201.pdf.

${ }^{134}$ See generally id.

${ }^{135}$ Kate Colpitts Hunter, Here There Be Pirates: How China is Meeting its IP Enforcement Obligations Under TRIPS, 8 SAN DIEGO INT’L L.J. 523, 551 (2007).
} 
retaliatory measures is not an effective solution. For example, the 1992 Memorandum of

Understanding signed between China and U.S. required China to

(1) adhere to certain levels of IP protection for patents, trade secrets, computer programs and sound recordings;

(2) accede to a number of important international intellectual property treaties, such as the Berne Convention ... ; and

(3) provide effective border control procedures and remedies. ${ }^{136}$

Although this Memorandum did result in new Chinese legislation for its copyright law, there was a lack of improved enforcement, as "piracy levels still remained among the highest in the world". ${ }^{137}$ The U.S., once again dissatisfied, labeled China a priority foreign country under Special 301 and threatened once more to impose strong trade sanctions. ${ }^{138}$ Further talks eventually led to the 1995 Memorandum of Understanding, which among other things required China to reduce piracy and improve enforcement. This again was ineffective. ${ }^{139}$

The widespread optimism among commentators that piracy and counterfeiting problems in China would effectively be resolved by filing a WTO complaint against China, demanding compliance under TRIPS, is understandable. The possibility for enforcement of the WTO dispute settlement decisions by withdrawal of trade concessions was one of the factors that motivated the U.S. to select the WTO as the alternative forum to WIPO. The benefits of the WTO system also included stability in the international trading system and a focus on rules rather than coercion.

Some commentators, however, have expressed the inadequacy of remedies provided under the WTO dispute settlement system. ${ }^{140}$ While the panel does give recommendations for the member

\footnotetext{
${ }^{136}$ Donald P. Harris, The Honeymoon is Over: The U.S.-China WTO Intellectual Property Complaint, 32 FORDHAM INT'L L.J. 96, 106 (2008); see also. Memorandum of Understanding on the Protection of Intellectual Property, U.S.P.R.C., arts. 1-6, Jan. 17, 1992, 34 I.L.M. 676.

${ }^{137}$ Harris, supra note 136, at 107.

${ }^{138}$ The U.S. threatened $\$ 3$ billion in punitive tariffs due to China's failure to enforce intellectual property. See Joseph A. Massey, The Emperor is Far Away: China's Enforcement of Intellectual Property Rights Protection 1986-2006, 7 CHI. J. INT'L L. 231, 235 (2006).

139 The U.S. losses were in the total of billions of dollars. Id.

${ }^{140}$ See generally William J. Davey, Compliance Problems in WTO Dispute Settlement, 42 CORNELL INT'L L.J. 119 (2009).
} 
country to bring itself to compliance, ${ }^{141}$ the WTO lacks enforcement powers. ${ }^{142}$ Once the panel or appellate body report is adopted, and a country fails to comply with the recommendations within a reasonable time, the complaining country is either to be compensated, for instance, by demanding tariff reductions, or if no satisfactory compensation is agreed upon, the complaining country is to impose trade sanctions such as suspending concessions or treaty obligations. ${ }^{143}$

In the matter of the WTO DS362 dispute, it can be strongly argued that if China does not comply with the recommendations by March 2010, "the [U.S.], now consuming more than $\$ 250$ billion in imports from China each year", has the incentive to retaliate by raising tariffs on Chinese goods. ${ }^{144}$ Although this strategy has worked for the U.S. with the European Community (EC), ${ }^{145}$ historical patterns reflect that imposing economic and trade sanctions will likely not work as effectively for China. In fact, unlike the EC, retaliation may not impose a sufficiently large economic loss for China. The EC's main exports are luxury products, as the Banana case exemplifies, ${ }^{146}$ where its sole market is the U.S. Conversely, most of Chinese exports are lower-end products that may be easily exported to alternative markets if retaliation shuts them out of the U.S. China may choose to live with the consequences of noncompliance if it does not strongly hurt China's economic regime. In fact, using sanctions at this point against China might hurt the U.S Much of what China exports to

\footnotetext{
${ }^{141}$ World Trade Organization, Settling Disputes, at 57-58, available at www.wto.org/english/thewto_e/whatis_e/tif_e/utw_chap3_e.pdf(last visited Nov. 14, 2009).

${ }^{142}$ See Mohammad Tanzimuddin Khan, WTO Dispute Settlement System and Developing Countries: A Neorealist Critique, Bangladesh Institute of International and Strategic Studies (Jun, 21. 2004), at 43-44 (Bliss Papers no. 21).

${ }^{143}$ World Trade Organization, supra note 141, at 58.

${ }^{144}$ Chad P. Bown, U.S.-China Trade Conflicts and the Future of the WTO, 33 FlETCHER F. WORLD AFF. 27, 35 (2009), available at http://fletcher.tufts.edu/forum/archives/pdfs/33-1pdfs/Bown.pdf.

${ }^{145}$ After the U.S. successfully challenged the EC's discriminatory import restrictions on Latin American-grown bananas that were distributed internationally by U.S. firms, "the EC refused to reform its banana import policy." Id. at 36. The U.S. sought authorization to retaliate, imposing tariffs on exports of a number of luxury goods from France, Italy, and other European countries. Id. at 27. This retaliatory measure by the U.S. eventually prompted the disposing of the banana policy by the EC. Id. See also Appellate Body Report, European Communities - Regime for the Importation, Sale and Distribution of Bananas, WT/DS27/AB/R (Sept. 9, 1997) (summarizing the Banana case). .

${ }^{146}$ Bown, supra note 144, 38-89. See e.g., Appellate Body Report, supra note 145.
} 
the U.S. derives from subsidiaries of U.S.-based multinational corporations. ${ }^{147}$ The U.S. would probably not prefer to "antagonize firms with significant U.S. shareholder interest.","148

Furthermore, the U.S. should be cautious to note that when filing IP-related complaints against China, China has had the tendency to respond with counter-attacks. For example, in 1995, the Chinese government refused to shut down twenty-nine factories which illegally produced approximately seventy million copies of American films and software every year. ${ }^{149}$ The U.S. eventually threatened to block China's effort in joining the WTO and to impose \$2.8 million in sanctions. ${ }^{150}$ China's response to U.S.'s threats was to take counter-retaliatory measures. ${ }^{151}$ China threatened, among other things, that it would "hold up applications of American companies ... to set up [business] in China" and would suspend talks with American automobile manufacturers over joint ventures. $^{152}$

China operates according to its interests, not foreign threats of economic or trade sanctions. The only way the WTO dispute settlement system seems to work effectively is through the good faith participation and cooperation of its members to assure that the system works properly. China had a purpose when it acceded into the WTO regime, focusing on the importance of trade considerations. As such, China knows that it will be in its interest that the WTO system function effectively, since it will not only be a respondent in the system, but will also be a complainant for future disputes. ${ }^{153}$ Therefore, China will be keen to reform and enforce its own law so that it is compatible with international frameworks of IP protection when its interests are at risk.

\footnotetext{
${ }^{147}$ Bown, supra note 144 , at 39.

${ }^{148} I d$.

${ }^{149}$ See David Sanger, U.S. Threatens \$2.8 Billion of Tariffs on China Exports, N.Y. TIMES, Jan. 1, 1995, at 114, available at http://www.nytimes.com/1995/01/01/world/us-threatens-2.8-billion-of-tariffs-on-china-exports.html.

${ }^{150} I d$.

${ }^{151} I d$.

${ }^{152} I d$.

${ }^{153}$ Id.
} 


\section{VIABLE SOLUTION: PLAYING THE WAITING GAME}

Since this paper argues that enforcing any external retaliatory measures or IPRs under TRIPS against China are inappropriate at this time, U.S. business owners with IP interests in China might be wondering what options remain.

Many commentators have blamed China for its lack of enforcement at the legislative level. As such, they have suggested the restructuring of China's IP statutes, especially those that demonstrate China's high threshold for criminal prosecution of IP violations. ${ }^{154}$ This paper, however, shows that often legislative change does not correlate to strong IPR enforcement.

Some scholars have hypothesized that the problem with enforcement lies in the Chinese intellectual property legal system, which places emphasis on compromise and harmony. These commentators argues that the system is ill-suited for the strong litigation that is necessary to enforce and defend IPRs in a market economy. ${ }^{155}$ Consequently, instead of allowing the individuals take part in the enforcement process, the Chinese government has chosen to deal with enforcement of IPR as a state-regulated matter. ${ }^{156}$ "The underlying view is that the legal system is one of many policy tools that the government disposes of .... Hence, the majority of copyright infringement cases are dealt with administratively.",157

Similarly, many claim that the primary reason for China's lack of enforcement, as well as inadequate legal system and IP laws, is due to the combination of Chinese communist culture and cultural roots in Confucianism. These cultures differ significantly from the U.S. capitalist culture. ${ }^{158}$ According to this theory, it is inevitable that Chinese culture favors group interests over individual interests. This directly contrasts with the U.S. ideal of individualism and its idea of IPRs. Alleged corruption and lack of will on the part of local authorities seems to contribute to a lack of

\footnotetext{
${ }^{154}$ Office of the U.S. Trade Rep., supra note 104, at 73.

${ }^{155}$ Hunter, supra note 135, at 528-29.

${ }^{156}$ Creemers, supra note 3 , at 14.

${ }^{157}$ Id. at 13.

${ }^{158}$ See generally ALFORD, supra note 115.
} 
enforcement. ${ }^{159}$ The U.S. once stated that China faces a "failure of will . . not a failure of ability," when it comes to enforcement of its copyright laws. ${ }^{160}$ To promote this, the U.S. evidenced that national government officials as well as local and national political leaders were involved and/or responsible for various pirating and counterfeiting undertakings. ${ }^{161}$ The corrupt Chinese officials would have no incentive to enforce copyright laws that would result in a loss of profits from pirated goods.

While it is true that China has been slow in reforming its IP regime, many commentators ignore the developments of IPR in the country that were implemented after its entry into the WTO. In 2002, the Chinese government initiated an anti-counterfeiting and anti-piracy campaign, which resulted in high numbers of seizures of infringing goods. ${ }^{162}$ With the assistance of the Chinese government, special intellectual property affairs departments and intellectual property protection networks were created. ${ }^{163}$ Furthermore, in 2002, China began allowing research firms to own statefunded patents. ${ }^{164}$ This move away from state ownership towards individual ownership shows an increase in Chinese citizens' interest in IP protection. Lastly, Chinese companies are becoming more IP savvy, becoming more innovators than copiers. ${ }^{165}$ "The patenting activities by Chinese companies reflect the progress of IP [development] in China."166 There has been a sharp rise on patenting worldwide by Chinese entities. In 2007, according to the WIPO, "there had been a 488

\footnotetext{
${ }^{159}$ See Jessica Jiong Zhou, Trademark Law \& Enforcement in China: A Transnational Perspective, 20 WIS. INT’L L. J. 415, 433 (2002) (explaining that despite China's quick move towards modernization, "some of its governmental bodies still hold on to their old bureaucratic habits ... [where] [f]iles are often passed around, lying beneath teacups on different desks without being read, and then joining previous backlogs and thrown into oblivion.").

${ }^{160}$ Sanger, supra note 149 .

${ }^{161} \mathrm{Id}$.

${ }^{162}$ Office of the U.S. Trade Rep., 2002 National Trade Estimate Report on Foreign Trade Barriers - China 58-59 (2002), http://ustraderep.gov/assets/Document_Library/Reports_Publications/2002/2002_NTE_Report/asset_upload_file317_63 86.pdf.

${ }^{163} \mathrm{Yu}$, supra note 119 , at 7.

${ }^{164}$ People's Daily Online (Beijing), China Allows Research Bodies to Own State-funded Patents, May 20, 2002, available at http://english.peopledaily.com.cn/200205/20/eng20020520_96080.shtml.

${ }^{165}$ Qian Huang \& Paul Devinsky, China - Home and Away: the Next IP Powerhouse, LAw360, at 2, http://www.mwe.com/info/pubs/law360_102109.pdf.

${ }^{166} I d$.
} 
percent increase in applications from Chinese domestic entities, and during the period from 2000 to 2006, China's share of worldwide patent fillings rose from 1.8 percent to 7.3 percent". ${ }^{167}$ During the same years, the total amount of patent applications filed worldwide by Chinese companies increased by 32.1 percent. $^{168}$

The Chinese have begun to realize the importance of a well-developed information economy and to notice the benefits of protecting IPRs, especially as more Chinese now understand the consequences of inadequate IP protection and how the lack of IP protection could gravely damage their country and its international reputation. The U.S., as well as many commentators, should acknowledge that, unlike its previous position which considered IPR as a bargaining chip, China is beginning to realize that IPRs can help promote national growth and prosperity.

In the light of these developments, the author proposes that the U.S. should wait and allow China to evolve into a country that is better ready to enforce IPRs. Historically, many less developed countries, including the U.S., which was a haven for the pirated works of Charles Dickens, ${ }^{169}$ as well as newly emerging industrialized countries, including Singapore and South Korea, ${ }^{170}$ experienced extensive significant piracy and counterfeiting activities before they reformed their intellectual property laws. In fact, the U.S. was one of the more notorious pirating nations in the world in the late eighteenth and early nineteenth centuries. ${ }^{171}$ Section 5 of the 1790 Copyright Act, the country's first copyright statute, stated explicitly that,

noting in this act shall be construed to extend to prohibit the importation or vending, reprinting or publishing within the United States, of any map, chart, book or books, written,

\footnotetext{
${ }^{167}$ Id. at 3; see generally, World Intellectual Property Organization, World Intellectual Property Indicators (2009), http://www.wipo.int/export/sites/www/ipstats/en/statistics/patents/pdf/wipo_pub_941.pdf. ${ }^{168} I d$.

${ }^{169}$ See Peter K. Yu, The Copyright Divide, 25 CARdozo L. Rev. 331, 336-53 (2003).

${ }^{170}$ See Robert M. SherwoOd, InTELleCtual Property AND ECONOMIC DEVElopment 155-156 (1990) (discussing the introduction of a modern copyright law in Singapore in the late 1980s and the adoption of modern patent and copyrights laws in South Korea in 1987).

${ }^{171}$ See James Boyle, Shamans, Software \& SpleEns: LaW And the Construction of the Information Society 3 (1996); Thomas Bender \& David Sampliner, Poets, Pirates, and the Creation of American Literature, 29 N.Y.U. J. INT'L L. \& Pol. 255, 255 (1997).
} 
printed, or published by any person not a citizen of the United States, in foreign parts or places without the jurisdiction of the United States. ${ }^{172}$

Congress did not extend copyright protection to foreign authors until more than a century later and only to those countries that offered the U.S. reciprocal copyright protection. ${ }^{173}$ As the former Register of Copyrights, Barbara Ringer, summarized: "Until the Second World War the United States had little reason to take pride in its international copyright relations . . its role in international copyright was marked by intellectual shortsightedness, political isolationism, and narrow economic self-interest." 174

If history is of any guide, most nations who value strong IPRs appear to have experienced a surge of commercial piracy at some point in their history as the country realizes substantial economic and technological growth. Allowing China additional time to progress to a stage in which IP protection is warranted may be the best option. According to an international commission set up by the British government to explore how national IP regimes could best be signed to benefit developing countries within the context of international agreements such as TRIPS, ${ }^{175}$ the commission warned:

$[\mathrm{R}]$ apid economic growth is more often associated with weaker IP protection. In technologically advanced developing countries, there is some evidence that IP protection becomes important at a stage of development, but that stage is not until a country is well into the category of upper middle income developing countries. ${ }^{176}$

\footnotetext{
172 Act of May 31, 1790, § 5, ch. 15, 1 Stat. 124 (1790) (emphasis added).

${ }^{173}$ International Copyright Act of March 3, 1891, ch. 565, 26 Stat. 1106 (1891). Under this Act, foreign authors received copyright protection when the President proclaimed that the foreign country provided American citizens with "the benefit of copyright on substantially the same basis as its own citizens" or that the country was a party to an international agreement that provided reciprocal protection to its members and to which "the United States may, at its pleasure, become a party." Id. at $\S 13$.

${ }^{174}$ Barbara A. Ringer, The Role of the United States in International Copyright - Past, Present, and Future, 56 GEO. L.J. 1050, 1051 (1968).

${ }^{175}$ Commission on Intellectual Property Rights, Integrating Intellectual Property Rights and Development Policy: Report of the Commission on Intellectual Property Rights 22 (2003), available at http://www.iprcommission.org/papers/pdfs/final_report/CIPRfullfinal.pdf. ${ }^{176} I d$.
} 
Yet despite the importance of waiting until China realizes that its overall benefits of IPR protection outweigh its overall economic costs, making it an upper middle income developing country, there is little if any empirical research concerning when a country such as China will reform its IPR regime. ${ }^{177}$ Additionally, according to the World Bank's 2008 Data, China was categorized as a lower middle-income economy country, ${ }^{178}$ implying that China has not reached the desired economic level to initiate a full range of IPR enforcement. However, according to scholar Peter $\mathrm{Yu}$, China does not seem far from this "crossover point" when the country will realize the importance of IPRs. ${ }^{179}$ There are primary motivators prevalent in China that evidence a rapid move towards full IP enforcement reform, such as (1) the improved "development of local stakeholders who benefit[]from stronger protection," (2) China's desire “to develop a knowledge-based economy," (3) China's "shift toward an export-driven economy," and (4) China's concern regarding its reputation within the international community. ${ }^{180}$

\section{CONCLUSION}

History has taught the U.S. that using retaliatory tactics to spur China to enforce its IP laws has had minimal effect in fighting against counterfeiting and piracy in China. For similar reasons, it seems the outcome of the WTO case between the U.S. and China under TRIPS, and the implementation of the WTO panel's recommendations by China, will most likely not render the effect desired by the U.S.

Stronger enforcement cannot be developed out of forced changes in Chinese domestic IP laws alone. Patience is needed for China to develop an environment in which the conditions necessary for successful IP reforms can be realized. These conditions include a "consciousness of legal rights ...,

\footnotetext{
177 Peter K. Yu, Intellectual Property, Economic Development, and the China Puzzle, in Intellectual Property, Trade and Development: Strategies to Optimize Economic DeVelopment in a Trips Plus Era 173, 202 (Daniel J. Gervais ed., 2007).

${ }^{178}$ World Bank, Country Groups, http://web.worldbank.org/WBSITE/EXTERNAL/DATASTATISTICS/0,,content MDK:20421402 pagePK:64133150 piPK:64133175 theSitePK:239419,00.html.

${ }^{179} \mathrm{Id}$.

${ }^{180} I d$. at 176.
} 
an effective and independent judiciary, a well-functioning innovative and competitive system, a sufficiently developed basic infrastructure, established business practices, . . . a critical mass of local stakeholders," and the Chinese people being educated about the importance of IP. ${ }^{181}$ Given the current international climate of insecurity and the U.S. economic crisis, the U.S. should be very cautious in instigating any conflict with China and should instead strength their cooperation with China and attempt to work with China to resolve their differences. ${ }^{182}$

\footnotetext{
${ }^{181}$ Peter K. Yu, The US-China WTO Cases Explained, MANAGING INTELL. ProP., at 4 (2009), available at http://www.peteryu.com/managingip_362.pdf.

${ }^{182}$ Statement before the House Committee on Foreign Affairs Subcommittee on Asia, the Pacific and the Global Environment Washington, DC, U.S.-China Relations: Maximizing the Effectiveness of the Strategic and Economic Dialogue, Sept. 10, 2009, http://www.state.gov/p/eap/rls/rm/2009/09/129103.htm.
} 